\title{
Improving plant bioaccumulation science through consistent reporting of experimental
} data

Fantke, Peter; Arnot, Jon A.; Doucette, William J.

Published in:

Journal of Environmental Management

Link to article, DOI:

10.1016/j.jenvman.2016.06.065

Publication date:

2016

Document Version

Peer reviewed version

Link back to DTU Orbit

Citation (APA):

Fantke, P., Arnot, J. A., \& Doucette, W. J. (2016). Improving plant bioaccumulation science through consistent reporting of experimental data. Journal of Environmental Management, 181, 374-384.

https://doi.org/10.1016/j.jenvman.2016.06.065

\section{General rights}

Copyright and moral rights for the publications made accessible in the public portal are retained by the authors and/or other copyright owners and it is a condition of accessing publications that users recognise and abide by the legal requirements associated with these rights.

- Users may download and print one copy of any publication from the public portal for the purpose of private study or research.

- You may not further distribute the material or use it for any profit-making activity or commercial gain

- You may freely distribute the URL identifying the publication in the public portal 
1 Improving plant bioaccumulation science through consistent reporting of

2 experimental data

3 Peter Fantke $^{\mathrm{a}^{*}}$, Jon A. Arnot ${ }^{\mathrm{b}, \mathrm{c}}$, William J. Doucette ${ }^{\mathrm{d}}$

$4{ }^{a}$ Quantitative Sustainability Assessment Division, Department of Management Engineering,

5 Technical University of Denmark, Produktionstorvet 424, 2800 Kgs. Lyngby, Denmark

$6{ }^{\mathrm{b}}$ ARC Arnot Research and Consulting, 36 Sproat Avenue, Toronto, Ontario, M4M 1W4,

7 Canada

$8{ }^{\mathrm{c}}$ Department of Physical and Environmental Sciences, University of Toronto Scarborough,

91265 Military Trail, Toronto, Ontario M1C 1A4, Canada

$10{ }^{\mathrm{d}}$ Utah Water Research Laboratory, Utah State University, 8200 Old Main Hill, Logan, Utah

$1184322-8200$, United States

12

13 *Corresponding author: Tel.: +45-452-54452; fax: +45-459-33435; Email: pefan@ dtu.dk 
14 TOCart

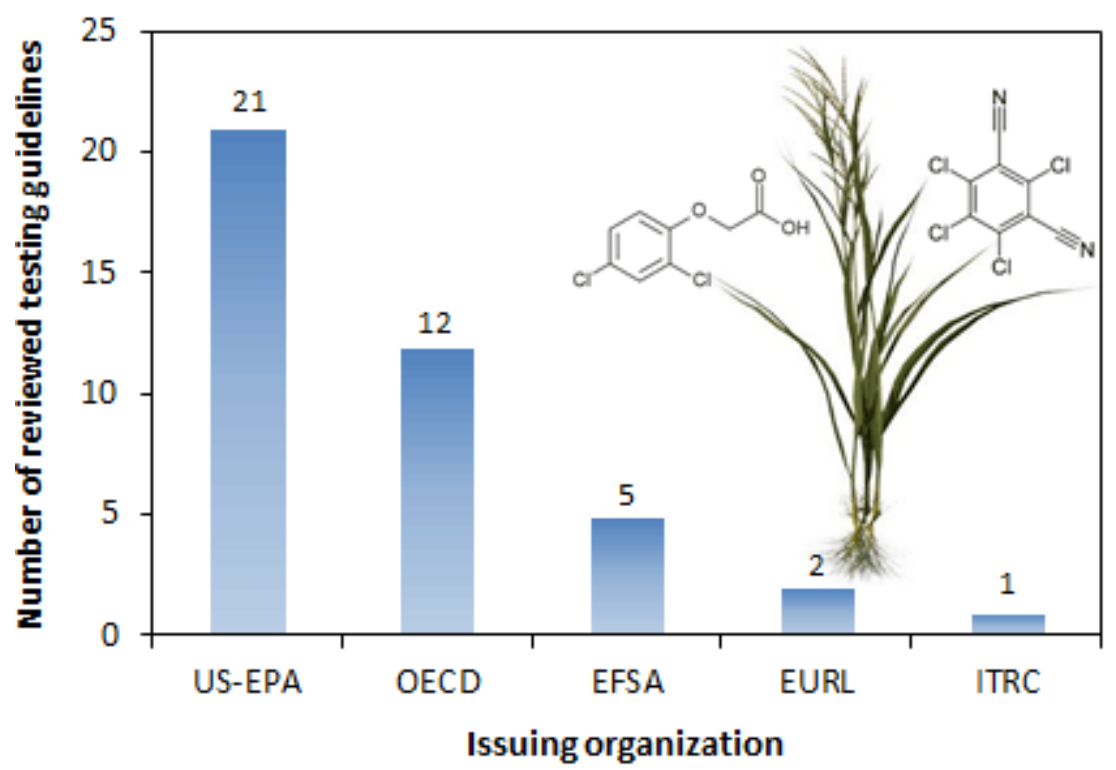

16 


\section{Abstract}

Experimental data and models for plant bioaccumulation of organic contaminants play a crucial role for assessing the potential human and ecological risks associated with chemical use. Plants are receptor organisms and direct or indirect vectors for chemical exposures to all other organisms. As new experimental data are generated they are used to improve our understanding of plant-chemical interactions that in turn allows for the development of better scientific knowledge and conceptual and predictive models. The interrelationship between experimental data and model development is an ongoing, never-ending process needed to advance our ability to provide reliable quality information that can be used in various contexts including regulatory risk assessment. However, relatively few standard experimental protocols for generating plant bioaccumulation data are currently available and because of inconsistent data collection and reporting requirements, the information generated is often less useful than it could be for direct applications in chemical assessments and for model development and refinement. We review existing testing guidelines, common data reporting practices, and provide recommendations for revising testing guidelines and reporting requirements to improve bioaccumulation knowledge and models. This analysis provides a list of experimental parameters that will help to develop high quality datasets and support modeling tools for assessing bioaccumulation of organic chemicals in plants and ultimately addressing uncertainty in ecological and human health risk assessments.

Keywords: bioaccumulation modeling; biotransformation; plant uptake; organic contaminants; reporting requirements; testing guidelines 


\section{Introduction}

Terrestrial plants constitute the largest global mass fraction of living organisms and are the primary food source for humans and most terrestrial animals (Houghton et al., 2009). Plants take up, translocate, transform, and accumulate organic chemicals that are not essential for plant growth and development (ITRC, 2011; U.S. EPA, 2012f), thereby contributing to the cycling of organic contaminants from local to global scales (Collins et al., 2011). Plants are subject to toxic effects from exposure to chemical stressors. Plants are also direct and indirect vectors for chemical exposures to higher trophic level organisms. Environmental concentrations and plant bioaccumulation (toxicokinetics) determine the likelihood for adverse effects to plants directly and to subsequent exposures and potential adverse effects to higher trophic level organisms. The extent of bioaccumulation is a function of substancespecific physicochemical properties, plant species-specific characteristics, and environmental conditions (Collins et al., 2011; Fantke et al., 2014; Trapp, 2015). Understanding plant uptake and bioaccumulation is crucial for a variety of regulatory applications including the authorization of formulations containing pesticides (EC, 2009) or biocides (EC, 1998), and for commercial chemicals falling under the REACH regulation (EC, 2006). Plant uptake has also been exploited to phytoremediate chemically contaminated sites and to delineate the extent of groundwater plumes using plants as biomonitors. The potential influence of plants in the overall fate and persistence of chemicals in the environment has been modelled at various scales but is largely unknown, particularly for chemicals that may be subject to degradation on or in plants (Cousins and Mackay, 2001; Undeman and McLachlan, 2011).

Experimentally, plant bioaccumulation data are collected from in vivo and in vitro studies. In vivo studies (field and greenhouse grown plants) usually focus on accumulation and dissipation from harvested plant components or whole plants and attempt to simulate realistic environmental conditions (Burrows et al., 2002). In contrast, in vitro studies (cell cultures) provide information on transport and degradation processes in plant cells under 
controlled laboratory conditions (Schwitzguébel et al., 2011). Data from in vivo and in vitro studies demonstrate the capacity of plants to biotransform and bioaccumulate a wide range of organic contaminants (Bacci et al., 1990; Eggen et al., 2011; Fantke and Juraske, 2013; Jones and Duarte-Davidson, 1997; Liu et al., 2009; Macherius et al., 2012; Mikes et al., 2009;

Samsøe-Petersen et al., 2002; Scheunert et al., 1994; Sharma et al., 2007; St-Amand et al., 2007; Stahl et al., 2009; Willis and McDowell, 1987). For most chemical-plant species combinations no experimental bioaccumulation and biotransformation data exist (Arnot et al., 2013; Fantke et al., 2014) and in the few cases where data are available, the critical information necessary to assess data reproducibility and interpretability are often lacking (Fantke and Juraske, 2013).

Mathematical models are used to complement expensive and time-consuming experimental studies for generalizing and extrapolating findings from specific experimental scenarios and as input for decisions in exposure- and risk-related science-policy fields.

Models thereby show considerable potential for improving the basic understanding of contaminant transport processes in plants (Gobas et al., 2016). In this study, we seek to help identifying key test parameters that are required to improve the interpretation and evaluation of plant bioaccumulation data, and to support the development, parameterization, application and evaluation of plant bioaccumulation models.

We first review existing plant bioaccumulation testing guidelines and their reporting requirements to identify whether information crucial for interpreting experimental data and for supporting modeling is reported. Next, we give a brief overview of data that are essential for developing and testing plant bioaccumulation models. Finally, we evaluate how data reporting requirements in current test protocols can be improved to better support the interpretation of experimental data and their use in plant bioaccumulation modeling. We will thereby emphasize that reporting the most relevant additional data is usually feasible and does not provide additional financial challenges. Overall, our study aims to improve the 
understanding of plant bioaccumulation in support of various regulatory and non-regulatory applications.

\section{Available bioaccumulation testing and data reporting guidelines}

2.1. Existing guidelines and their scope

Current plant bioaccumulation testing guidelines were reviewed $(n=41)$ with focus on the following key question: Do the reporting recommendations in current testing guidelines include the key parameters needed to adequately interpret and quantify the experimental results and facilitate the use of measured data in models for risk and impact assessment? Guidelines were categorized according to their relevance for quantifying bioaccumulation and/or biotransformation in terrestrial plants via modeling approaches. High relevance is given when either plant uptake, accumulation or transformation/other removal was addressed in a quantitative way. Medium relevance is given when uptake, accumulation or transformation was addressed, but could not be quantitatively associated with chemical application (e.g. pesticides) or emission or when specifically residue sampling and analysis procedures were addressed. Low relevance is given when neither plant uptake, accumulation or transformation was the focus, but when other metrics associated with plant bioaccumulation were addressed, such as crop damage, human contact levels (as input for occupational exposure), or transformation products in soil that could enter the plant.

Few guidelines from national and international organizations address one or more aspects involved in the testing of uptake, translocation and bioaccumulation of chemicals in plants as listed in Table 1. The U.S. Environmental Protection Agency (US-EPA) established a series of ecological effect, residue chemistry, fate, transport and transformation, as well as occupational and residential exposure test guidelines developed by the Office of Chemical Safety and Pollution Prevention and the Office of Prevention, Pesticides and Toxic

Substances for use in the experimental testing of chemicals (U.S. EPA, 1996a, b, c, d, e, f, g, 
h, i, j, k, 1, m, 2008a, b, 2012a, b, c, d, e, f). The EU Reference Laboratories for Residues of

119 Pesticides (EURL) and the European Food Safety Authority (EFSA) developed guidelines

120 focusing on the sampling of plants in the frame of pesticide residue testing (EFSA, 2010,

121 2012, 2013, 2014a, b; EU RLRP, 2011, 2013). The Interstate Technology and Regulatory

122 Council (ITRC) provides guidelines for the evaluation of contaminated sediment sites,

123 thereby also addressing plant uptake (ITRC, 2011). Finally the Organisation for Economic

124 Co-operation and Development (OECD) established several guidelines for the testing of

125 chemicals for use in studies measuring the distribution of chemicals in the plant environment

126 (OECD, 1992, 1997, 2002, 2006a, b, 2007a, b, c, d, e, 2008, 2009).

128 Table 1 Existing guidelines and standards for different contexts of testing bioaccumulation of

129 chemicals in plants, plant environments and plant-based commodities, and their relevance for

130 quantification of bioaccumulation and/or biotransformation in terrestrial plants.

\begin{tabular}{|c|c|c|c|}
\hline $\begin{array}{l}\text { Issuing } \\
\text { organization }\end{array}$ & Guideline & Purpose & Relevance \\
\hline \multirow[t]{4}{*}{$\begin{array}{l}\text { U.S. } \\
\text { Environmental } \\
\text { Protection } \\
\text { Agency }\end{array}$} & $\begin{array}{l}\text { Fate, Transport and } \\
\text { Transformation Test } \\
\text { Guidelines: Terrestrial Field } \\
\text { Dissipation, OPPTS } 835.6100 \\
\text { (U.S. EPA, 2008a) }\end{array}$ & $\begin{array}{l}\text { Plant uptake is assessed as one of } \\
\text { several field dissipation pathways; } \\
\text { restricted to pesticides; } \\
\text { bioaccumulation or } \\
\text { biotransformation in plants not } \\
\text { considered }\end{array}$ & Medium \\
\hline & $\begin{array}{l}\text { Fate, Transport and } \\
\text { Transformation Test } \\
\text { Guidelines: Forestry } \\
\text { Dissipation, OPPTS } 835.6300 \\
\text { (U.S. EPA, 2008b) }\end{array}$ & $\begin{array}{l}\text { Uptake into tree litter assessed as } \\
\text { one of several field dissipation } \\
\text { pathways; restricted to } \\
\text { bioaccumulation in tree litter, soil } \\
\text { and water }\end{array}$ & High \\
\hline & $\begin{array}{l}\text { Ecological Effects Test } \\
\text { Guidelines: Background and } \\
\text { Special Considerations - Tests } \\
\text { with Terrestrial and Aquatic } \\
\text { Plants, Cyanobacteria, and } \\
\text { Terrestrial Soil-Core } \\
\text { Microcosms, OCSPP } \\
850.4000 \text { (U.S. EPA, 2012a) }\end{array}$ & $\begin{array}{l}\text { Exposure damage to plants and } \\
\text { other organisms including non- } \\
\text { target plants is assessed; } \\
\text { quantitative bioaccumulation or } \\
\text { biotransformation not considered }\end{array}$ & Low \\
\hline & $\begin{array}{l}\text { Ecological Effects Test } \\
\text { Guidelines: Seedling }\end{array}$ & $\begin{array}{l}\text { Effects of substances on plants } \\
\text { during early critical development }\end{array}$ & Low \\
\hline
\end{tabular}




\begin{tabular}{|c|c|c|c|}
\hline $\begin{array}{l}\text { Issuing } \\
\text { organization }\end{array}$ & Guideline & Purpose & Relevance \\
\hline & $\begin{array}{l}\text { Emergence and Seedling } \\
\text { Growth, OCSPP } 850.4100 \\
\text { (U.S. EPA, 2012b) }\end{array}$ & $\begin{array}{l}\text { stages are measured; quantitative } \\
\text { bioaccumulation or } \\
\text { biotransformation not considered }\end{array}$ & \\
\hline & $\begin{array}{l}\text { Ecological Effects Test } \\
\text { Guidelines: Vegetative Vigor, } \\
\text { OCSPP } 850.4150 \text { (U.S. EPA, } \\
\text { 2012c) }\end{array}$ & $\begin{array}{l}\text { Effects of foliar applied substances } \\
\text { on plants during vegetative growth } \\
\text { are measured; restricted to spray } \\
\text { application (i.e. not applicable for } \\
\text { root uptake); quantitative } \\
\text { bioaccumulation or } \\
\text { biotransformation not considered }\end{array}$ & Low \\
\hline & $\begin{array}{l}\text { Ecological Effects Test } \\
\text { Guidelines: Early Seedling } \\
\text { Growth Toxicity Test, OCSPP } \\
850.4230 \text { (U.S. EPA, 2012d) }\end{array}$ & $\begin{array}{l}\text { Data on the phytotoxicity of } \\
\text { substances are provided; } \\
\text { quantitative bioaccumulation or } \\
\text { biotransformation not considered }\end{array}$ & Low \\
\hline & $\begin{array}{l}\text { Ecological Effects Test } \\
\text { Guidelines: Terrestrial Plants } \\
\text { Field Study, OCSPP } 850.4300 \\
\text { (U.S. EPA, 2012e) }\end{array}$ & $\begin{array}{l}\text { Field experiments with focus on } \\
\text { plant damage are conducted; } \\
\text { bioaccumulation or } \\
\text { biotransformation not considered }\end{array}$ & Low \\
\hline & $\begin{array}{l}\text { Ecological Effects Test } \\
\text { Guidelines: Plant Uptake and } \\
\text { Translocation Test, OCSPP } \\
850.4800 \text { (U.S. EPA, 2012f) }\end{array}$ & $\begin{array}{l}\text { Data on the quantity of substances } \\
\text { incorporated in plant tissues and } \\
\text { the potential for entry into food } \\
\text { chains are provided; consideration } \\
\text { of quantitative plant uptake and } \\
\text { bioaccumulation }\end{array}$ & High \\
\hline & $\begin{array}{l}\text { Residue Chemistry Test } \\
\text { Guidelines: Nature of the } \\
\text { Residue - Plants, Livestock, } \\
\text { OPPTS } 860.1300 \text { (U.S. EPA, } \\
\text { 1996d) }\end{array}$ & $\begin{array}{l}\text { Qualitative metabolic fate of an } \\
\text { active ingredient applied to a plant } \\
\text { is assessed; quantitative } \\
\text { bioaccumulation or } \\
\text { biotransformation not considered; } \\
\text { restricted to pesticides }\end{array}$ & High \\
\hline & $\begin{array}{l}\text { Residue Chemistry Test } \\
\text { Guidelines: Residue } \\
\text { Analytical Method, OPPTS } \\
860.1340 \text { (U.S. EPA, 1996e) }\end{array}$ & $\begin{array}{l}\text { Analytical methods are tested to } \\
\text { determine all components of the } \\
\text { total toxic residue; quantitative } \\
\text { bioaccumulation or } \\
\text { biotransformation not considered }\end{array}$ & Medium \\
\hline & $\begin{array}{l}\text { Residue Chemistry Test } \\
\text { Guidelines: Multiresidue } \\
\text { Method, OPPTS } 860.1360 \\
\text { (U.S. EPA, 1996f) }\end{array}$ & $\begin{array}{l}\text { Analytical methods are applied to } \\
\text { confirm the presence or absence of } \\
\text { many pesticides and their } \\
\text { metabolites in commodities; } \\
\text { quantitative bioaccumulation or } \\
\text { biotransformation not considered }\end{array}$ & Low \\
\hline & $\begin{array}{l}\text { Residue Chemistry Test } \\
\text { Guidelines: Storage Stability } \\
\text { Data, OPPTS } 860.1380 \text { (U.S. } \\
\text { EPA, 1996g) }\end{array}$ & $\begin{array}{l}\text { Stability or decomposition rate of } \\
\text { total toxic residue in or on } \\
\text { raw/processed agricultural } \\
\text { commodity between harvest or }\end{array}$ & Medium \\
\hline
\end{tabular}




\begin{tabular}{ll}
\hline $\begin{array}{l}\text { Issuing } \\
\text { organization }\end{array}$ & Guideline \\
\hline & \\
& \\
& Residue Chemistry Test \\
& Guidelines: Water, Fish, and \\
& Irrigated Crops, OPPTS \\
& 860.1400 (U.S. EPA, 1996h)
\end{tabular}

Purpose

Relevance

sample collection and analysis are

validated; quantitative

bioaccumulation or

biotransformation not considered

Levels of pesticide residues are

High

assessed in water, fish, and

irrigated crops; restricted to

application to water to control

aquatic pests; restricted to

pesticides

Residue Chemistry Test

Magnitude of pesticide residues are

High

Guidelines: Crop Field Trials,

OPPTS 860.1500 (U.S. EPA, 1996i)

assessed in or on raw agricultural

commodities; designed for field

experiments, but restricted to

pesticides

Residue Chemistry Test

Guidelines: Processed

It is assessed whether residues in

raw commodities may be expected

Food/Feed, OPPTS 860.1520

(U.S. EPA, 1996j)

to degrade or concentrate during

food processing (i.e. not applicable

for plant uptake); restricted to time

after harvest, restricted to

pesticides

Residue Chemistry Test

Tolerance levels are obtained

Low

Guidelines: Proposed

based on maximum residues during

Tolerances, OPPTS 860.1550

(U.S. EPA, 1996k)

field trials; quantitative

bioaccumulation or

biotransformation not considered

Residue Chemistry Test

Nature and amount of pesticide

residue uptake in rotational crops

High

Guidelines: Confined

are assessed; restricted to

Accumulation in Rotational

pesticides

Crops, OPPTS
EPA, 19961)

Residue Chemistry Test

Guidelines: Field

Amount of pesticide residue uptake

High

Accumulation in Rotational

in rotational crops is assessed

under actual field-use conditions;

Crops, OPPTS 860.1900 (U.S. restricted to pesticides

EPA, 1996m)

Occupational and Residential

Exposure Test Guidelines:

Background for Post-

application Exposure

Monitoring Test Guidelines,

OPPTS 875.2000 (U.S. EPA, 1996a)

Time necessary is assessed for

Low pesticide residues at the treated site to decline to allowable human reentry levels (i.e. not applicable for plant uptake); restricted to pesticides

High 


\begin{tabular}{|c|c|c|c|}
\hline \multirow{3}{*}{$\begin{array}{l}\text { Issuing } \\
\text { organization }\end{array}$} & Guideline & Purpose & Relevance \\
\hline & $\begin{array}{l}\text { Occupational and Residential } \\
\text { Exposure Test Guidelines: } \\
\text { Foliar Dislodgeable Residue } \\
\text { Dissipation, OPPTS } 875.2100 \\
\text { (U.S. EPA, 1996b) }\end{array}$ & $\begin{array}{l}\text { Pesticide residues are assessed } \\
\text { which are deposited on and remain } \\
\text { on surfaces after pesticide } \\
\text { application (i.e. not applicable for } \\
\text { plant uptake); restricted to } \\
\text { pesticides }\end{array}$ & Medium \\
\hline & $\begin{array}{l}\text { Occupational and Residential } \\
\text { Exposure Test Guidelines: } \\
\text { Data Reporting and } \\
\text { Calculations, OPPTS } \\
875.2900 \text { (U.S. EPA, 1996c) }\end{array}$ & $\begin{array}{l}\text { Detectable dislodgeable residues } \\
\text { are assessed of the pesticide on } \\
\text { surfaces to which the pesticide was } \\
\text { applied (i.e. not applicable for } \\
\text { plant uptake); restricted to } \\
\text { pesticides }\end{array}$ & Low \\
\hline \multirow[t]{2}{*}{$\begin{array}{l}\text { EU Reference } \\
\text { Laboratories } \\
\text { for Residues of } \\
\text { Pesticides }\end{array}$} & $\begin{array}{l}\text { Method Validation \& Quality } \\
\text { Control Procedures for } \\
\text { Pesticide Residues Analysis in } \\
\text { Food \& Feed, } \\
\text { SANCO/12495/2011 (EU } \\
\text { RLRP, 2011) }\end{array}$ & $\begin{array}{l}\text { Sampling procedure is evaluated as } \\
\text { part of laboratory tests (i.e. not } \\
\text { applicable for plant uptake or } \\
\text { transformation tests); restricted to } \\
\text { pesticides }\end{array}$ & Medium \\
\hline & $\begin{array}{l}\text { Guidance Document on } \\
\text { Analytical Quality Control and } \\
\text { Validation Procedures for } \\
\text { Pesticide Residues Analysis in } \\
\text { Food and Feed, } \\
\text { SANCO/12571/2013 (EU } \\
\text { RLRP, 2013) }\end{array}$ & $\begin{array}{l}\text { Sampling procedure and sampling } \\
\text { quality control are evaluated as } \\
\text { part of laboratory tests (i.e. not } \\
\text { applicable for plant uptake or } \\
\text { transformation tests); restricted to } \\
\text { pesticides }\end{array}$ & Medium \\
\hline \multirow[t]{3}{*}{$\begin{array}{l}\text { European Food } \\
\text { Safety } \\
\text { Authority }\end{array}$} & $\begin{array}{l}\text { Standard Sample Description } \\
\text { for Food and Feed (EFSA, } \\
2010)\end{array}$ & $\begin{array}{l}\text { Sampling procedure is evaluated as } \\
\text { part of laboratory tests (i.e. not } \\
\text { applicable for plant uptake or } \\
\text { transformation tests); restricted to } \\
\text { pesticides }\end{array}$ & Medium \\
\hline & $\begin{array}{l}\text { Use of the EFSA Standard } \\
\text { Sample Description for the } \\
\text { Reporting of Data on the } \\
\text { Control of Pesticide Residues } \\
\text { in Food and Feed According to } \\
\text { Regulation (EC) No 396/2005; } \\
\text { including revision } 1 \text { and } \\
\text { version } 2013 \text { data collection } \\
\text { (EFSA, 2012, 2013, 2014b) }\end{array}$ & $\begin{array}{l}\text { Sampling procedure is evaluated } \\
\text { part of laboratory tests for the } \\
\text { reporting of the national results of } \\
\text { the pesticide monitoring (i.e. not } \\
\text { applicable for plant uptake or } \\
\text { transformation tests); restricted to } \\
\text { pesticides }\end{array}$ & Medium \\
\hline & $\begin{array}{l}\text { EFSA Guidance Document for } \\
\text { Evaluating Laboratory and } \\
\text { Field Dissipation Studies to } \\
\text { Obtain DegT50 Values of } \\
\text { Active Substances of Plant } \\
\text { Protection Products and } \\
\text { Transformation Products of }\end{array}$ & $\begin{array}{l}\text { Degradation rates of active } \\
\text { substances and transformation } \\
\text { products in soil are assessed and } \\
\text { crop interception values are } \\
\text { selected (i.e. not applicable for } \\
\text { plant uptake or transformation } \\
\text { tests); restricted to pesticides }\end{array}$ & Low \\
\hline
\end{tabular}




\begin{tabular}{llcl}
\hline $\begin{array}{l}\text { Issuing } \\
\text { organization }\end{array}$ & Guideline & Purpose & Relevance \\
\hline
\end{tabular}

these Active Substances in

Soil (EFSA, 2014a)

\begin{tabular}{|c|c|c|c|}
\hline $\begin{array}{l}\text { Interstate } \\
\text { Technology } \\
\text { and Regulatory } \\
\text { Council }\end{array}$ & $\begin{array}{l}\text { Incorporating Bioavailability } \\
\text { Considerations into the } \\
\text { Evaluation of Contaminated } \\
\text { Sediment Sites (ITRC, 2011) }\end{array}$ & $\begin{array}{l}\text { Plant uptake is assessed as one out } \\
\text { of several considered pathways of } \\
\text { sediment dissipation; } \\
\text { bioaccumulation or } \\
\text { biotransformation in plants not } \\
\text { considered }\end{array}$ & Medium \\
\hline \multirow[t]{2}{*}{$\begin{array}{l}\text { Organisation } \\
\text { for Economic } \\
\text { Co-operation } \\
\text { and } \\
\text { Development }\end{array}$} & $\begin{array}{l}\text { OECD Guidelines for the } \\
\text { Testing of Chemicals, } \\
\text { Terrestrial Plant Test: Seedling } \\
\text { Emergence and Seedling } \\
\text { Growth Test, Test no. } 208 \\
\text { (OECD, 2006a) }\end{array}$ & $\begin{array}{l}\text { Negative effects on seedling } \\
\text { emergence and growth are } \\
\text { assessed; restricted to soil } \\
\text { application (i.e. not applicable for } \\
\text { foliar uptake); bioaccumulation or } \\
\text { biotransformation not considered }\end{array}$ & Low \\
\hline & $\begin{array}{l}\text { OECD Guidelines for the } \\
\text { Testing of Chemicals, } \\
\text { Terrestrial Plant Test: } \\
\text { Vegetative Vigour Test, Test } \\
\text { no. } 227 \text { (OECD, 2006b) }\end{array}$ & $\begin{array}{l}\text { Negative effects on vegetative } \\
\text { vigor of plants are assessed; } \\
\text { restricted to spray application (i.e. } \\
\text { not applicable for root uptake); } \\
\text { bioaccumulation or } \\
\text { biotransformation not considered }\end{array}$ & Low \\
\hline
\end{tabular}

OECD Guidelines for the

Testing of Chemicals: Ready

Chemicals are screened for ready Medium

Biodegradability, Test no. 301

(OECD, 1992)

biodegradability in an aerobic

aqueous medium; not applicable

for plant uptake or plant tissue

sample testing

OECD Guidelines for the

Aerobic and anaerobic

Low

Testing of Chemicals: Aerobic transformation in soil is evaluated;

and Anaerobic Transformation includes formation and decline of

in Soil, Test no. 307 (OECD, transformation products (i.e. not

2002)

applicable for plant uptake or

transformation tests)

OECD Guidelines for the

Testing of Chemicals:

Total radioactive residues,

transformation products and

Metabolism in Crops, Test no. pathways are estimated in crops

501 (OECD, 2007a)

after treatment; rates of uptake and

degradation not considered;

intended for pesticides

OECD Guidelines for the

Testing of Chemicals:

Potential of chemicals and their soil transformation products to

Metabolism in Rotational accumulate in rotational crops is

Crops, Test no. 502 (OECD, assessed; restricted to pesticides

High 2007b)

OECD Guidelines for the

Testing of Chemicals:

Residues from accumulation in rotational crops via soil uptake

High

High 


\begin{tabular}{llll}
\hline $\begin{array}{l}\text { Issuing } \\
\text { organization }\end{array}$ & Guideline & Purpose & Relevance \\
\hline
\end{tabular}

Residues in Rotational Crops, under field conditions are assessed;

Limited Field Studies, Test no. restricted to pesticides

$504(\mathrm{OECD}, 2007 \mathrm{c})$

OECD Guidelines for the Stability time period in crop Low

Testing of Chemicals: Stability commodities is analyzed between

of Pesticide Residues in Stored sampling and analysis (i.e. not

Commodities, Test no. 506 applicable for plant uptake or

(OECD, 2007d)

transformation tests)

OECD Guidelines for the Magnitude of residues in processed Medium

Testing of Chemicals: Nature food commodities is assessed

of the Pesticide Residues in (compared to raw agricultural

Processed Commodities - High commodities); restricted to post-

Temperature Hydrolysis, Test harvest processes

no. 507 (OECD, 2007e)

OECD Guidelines for the

Testing of Chemicals:

Magnitude of the Pesticide

Residues in Processed

Commodities, Test no. 508

(OECD, 2008)

OECD Guidelines for the

Testing of Chemicals: Crop

Field Trial, Test no. 509

(OECD, 2009)

OECD Series on Testing and

Assessment, Guidance

Document for the Conduct of

Studies of Occupational

Exposure to Pesticides During

Agricultural Application,

OCDE/GD(97)148 (OECD, 1997)
132 2.2. The role of data reporting requirements

Most test guidelines provide general reporting recommendations for test species,

134 pathway analysis and sample extraction. Of these, some US-EPA and OECD guidelines

135 provide a good starting point to improve the quantitative understanding of bioaccumulation

136 and biotransformation in plants. These guidelines focus on general bioaccumulation in plant
Distribution of residues of active High ingredients and degradation products is quantified in processed commodities resulting from processing; not applicable for plant uptake; restricted to post-harvest processes

Magnitude of residues is assessed

High in or on raw agricultural commodities and dissipation rate after field application; restricted to pesticides

Worker exposure during and after field application of pesticides is assessed (i.e. not applicable for plant uptake or transformation tests); restricted to pesticides

Low 
137 tissue (U.S. EPA, 2012f), biotransformation in crops (OECD, 2007a) and rotational crops

138 (OECD, 2007b), accumulation of pesticides in rotational crops under confined (U.S. EPA, 139 19961) and actual field conditions (OECD, 2007c; U.S. EPA, 1996m), and residual pesticide

140 concentrations and biotransformation after harvest in raw (OECD, 2009; U.S. EPA, 1996i)

141 and processed agricultural crop-based commodities (OECD, 2008; U.S. EPA, 1996j). EURL

142 provides extensive reporting guidelines for sampling of pesticide residues in plants (EU

143 RLRP, 2011, 2013). A key limitation is that none of the existing guidelines discusses or

144 provides guidance on how to further use the experimental data (study conditions,

145 measurement results, etc.) to support plant bioaccumulation modeling that is used to

146 complement experimental data in several science-policy fields. Further, except EURL (EU

147 RLRP, 2011, 2013), existing guidelines do not provide information on how to determine

148 uncertainty associated with measurement, sampling and analytical tools with respect to a

149 standardized interpretability of different testing designs and with respect to reporting

150 measurement uncertainty.

151 All in all, there is no existing testing guideline that provides sufficient information of

152 how to consistently report and interpret testing data or how to use experimental results as such

153 and as input in plant bioaccumulation models applied in regulation and decision support. Most

154 importantly, guidelines do not include requirements for relevant plant and exposure medium

155 characteristics, relevant environmental condition parameters, and applied formulation and

156 substance properties, although most of these aspects can be readily obtained and do not

157 require additional experimental equipment. As a consequence, current data reporting gaps in

158 experimental testing studies and underlying guidelines are recognized important limitations in

159 plant bioaccumulation models (Arnot et al., 2013; Environment Agency, 2006; Fantke and

160 Juraske, 2013; Fryer and Collins, 2003; Gobas et al., 2016; McKone and Maddalena, 2007).

161 However, several existing guidelines already provide a good starting point in terms of data

162 reporting requirements and these guidelines could be slightly modified to provide critical 
163 information that could be used to improve plant bioaccumulation modeling. For that, it is

164 important to understand the data that are required in bioaccumulation modeling, which is 165 outlined in the following.

\section{Plant bioaccumulation models and their application}

168 3.1. Framework for plant bioaccumulation modeling

Mathematical models are often used to better understand experimental data obtained under defined test conditions. Models also help the extrapolation of experimental data from defined test conditions to specific environmental scenarios in an attempt to address various regulatory questions. Key processes described in plant bioaccumulation models are direct application onto the plant (e.g. agricultural pesticide applications), gaseous and dry/wet particle deposition from air onto cuticles, evaporation from cuticles and transpiration through leaf stomata, root uptake with soil pore water, diffusion between soil gas and root phases, chemical and microbial transformation in plant tissue, chemical partitioning between tissues and phases, as well as translocation with xylem transpiration and phloem assimilation streams. Furthermore, re-volatilization from soil, leaching toward groundwater, soil surface run-off, wash-off from plants, wind-drift in air and plant growth are often modeled processes influencing the distribution and accumulation of chemicals in plants. Detailed process descriptions are found elsewhere (Collins et al., 2006; Collins et al., 2011; Fantke et al., 2011; Riederer, 1990; Trapp and Legind, 2011; Trapp and Mc Farlane, 1995). Different types of

183 plant bioaccumulation models are described elsewhere (e.g. Gobas et al., 2016). Models are generally not accepted until they can be evaluated using results from tests collected under a variety of conditions. Most models rely on measured data from field and laboratory tests with respect to various input variables (e.g. air temperature, plant water content) and process-related parameters (e.g. degradation rates in plant components), depending on each model's scope and level of detail. Fig. 1 shows conceptually how key 
uptake, partitioning, translocation and degradation processes measured in experimental plant

190 bioaccumulation tests (Fig. 1a) can be translated into modeled systems based on

191 interconnected environmental and plant compartments (Fig. 1b).

192

(a) Bioaccumulation processes

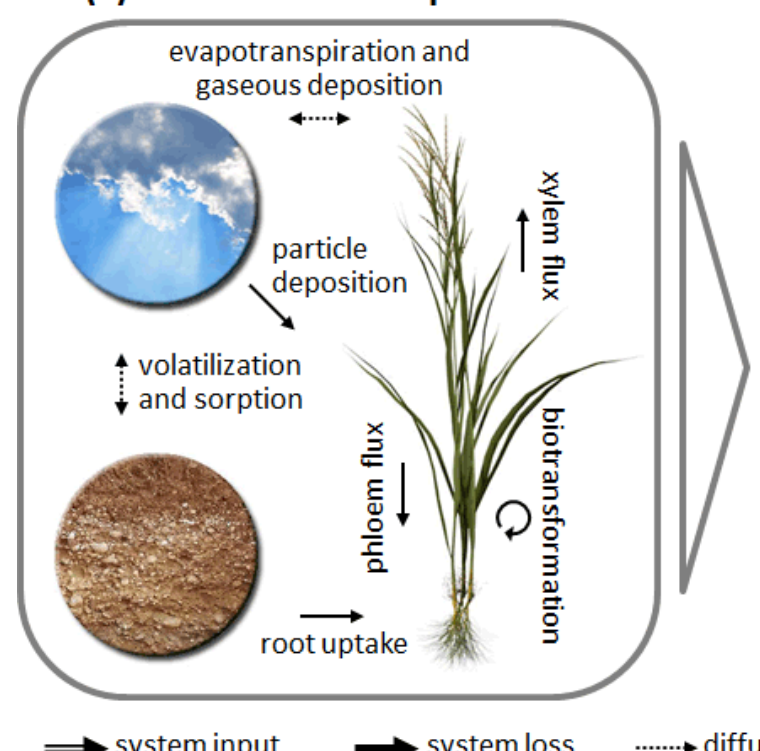

(b) Example bioaccumulation model design

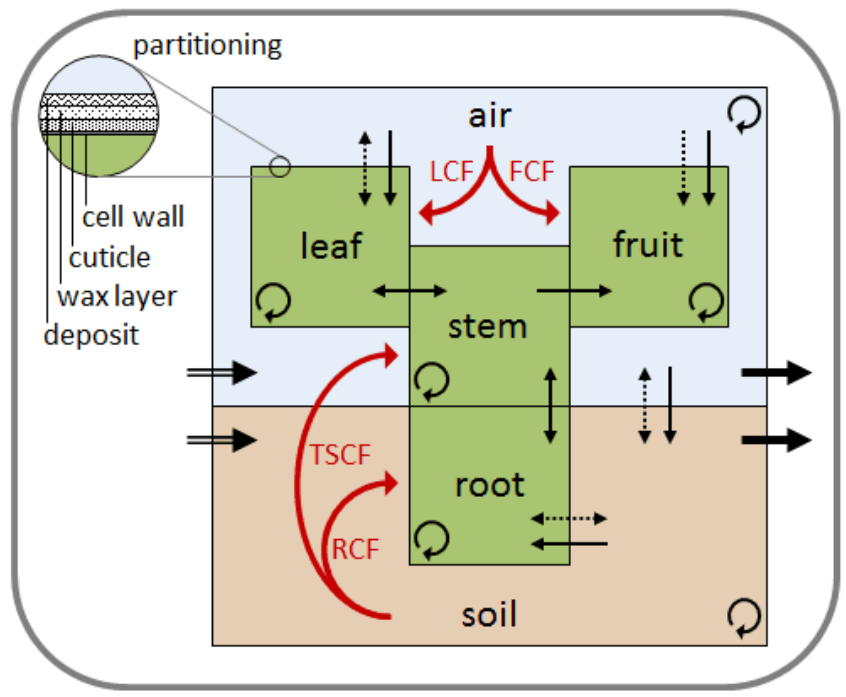

194 Fig. 1 - Schematic representation of main processes relevant in plant bioaccumulation studies

195 (a) and their representation in a mechanistic plant bioaccumulation models (b): Red arrows

196 indicate steady-state concentration ratios between leaf (LCF), fruit (FCF), stem (TSCF), root

197 (RCF) and external solution, respectively; black arrows indicate process rates.

\subsection{Input data requirements}

Typically, when doing experiments more data are collected then reported in

experimental plant bioaccumulation studies, often because it is not clear which of the

measured data are in fact useful as relevant aspects for decisions and/or as input for models.

To address the latter, the present section provides insight into typical input data requirements for plant bioaccumulation models.

In a typical mass balance model (Fig. 1b), bioaccumulation of a chemical is the net 
aerial surfaces, predominantly leaves) and soil (via roots). Elimination of chemicals from

208 plants includes losses to the environment (e.g. volatilization), losses due to plant growth 209 (biodilution), and degradation within plants. To quantify these processes, input data are required for each level of model detail and scope. For example, to estimate chemical uptake

211 through the air-leaf interface, a simple model might require the leaf concentration factor

212 (LCF, Fig. 1b) defined as the concentration ratio in leaf and in air at equilibrium (Calamari,

213 1993). In contrast, a more complex model might quantify each competitive process

214 contributing to leaf uptake, such as dry and wet deposition, as a function of particle concentration, aerosol washout and rain occurrence in air (Fantke et al., 2011), diffusion through the leaf-air boundary layer derived from stomatal and cuticular resistances (Schreiber and Schönherr, 2009), and concentration dilution as function of plant growth rates. In any case, specific input variables must be given to model plant uptake. If these input variables cannot be estimated based on e.g. available regressions, models rely on experimental studies to obtain required input data. Input variables that are reported in 25 plant uptake modeling studies to strongly affect bioaccumulation processes and that typically have to be obtained from experimental testing studies are listed in Table 2.

Partition coefficients $\mathrm{K}_{\mathrm{OW}}$ and $\mathrm{K}_{\mathrm{Aw}}$ along with half-lives in plants are by far the substance properties most frequently reported to be relevant for plant bioaccumulation modeling followed by molecular mass and $\mathrm{pKa}$. Most frequently reported plant characteristics are plant lipid and water contents, growth rates, and xylem flow (transpiration stream). Air 227 temperature and soil organic carbon (OC) content are the most frequently reported 228 environmental conditions relevant for plant bioaccumulation modeling along with scenariospecific time between substance application (e.g. in case of intentionally applied pesticides)

230 and plant harvest. Many additional parameters are less frequently reported to be relevant (see

231 Table 2). This demonstrates that generally multiple parameters are required as input for

232 bioaccumulation models including substance properties, plant characteristics, and 
234 experimental testing studies.

236 Table 2 Relevant input parameters identified in 25 plant bioaccumulation models.

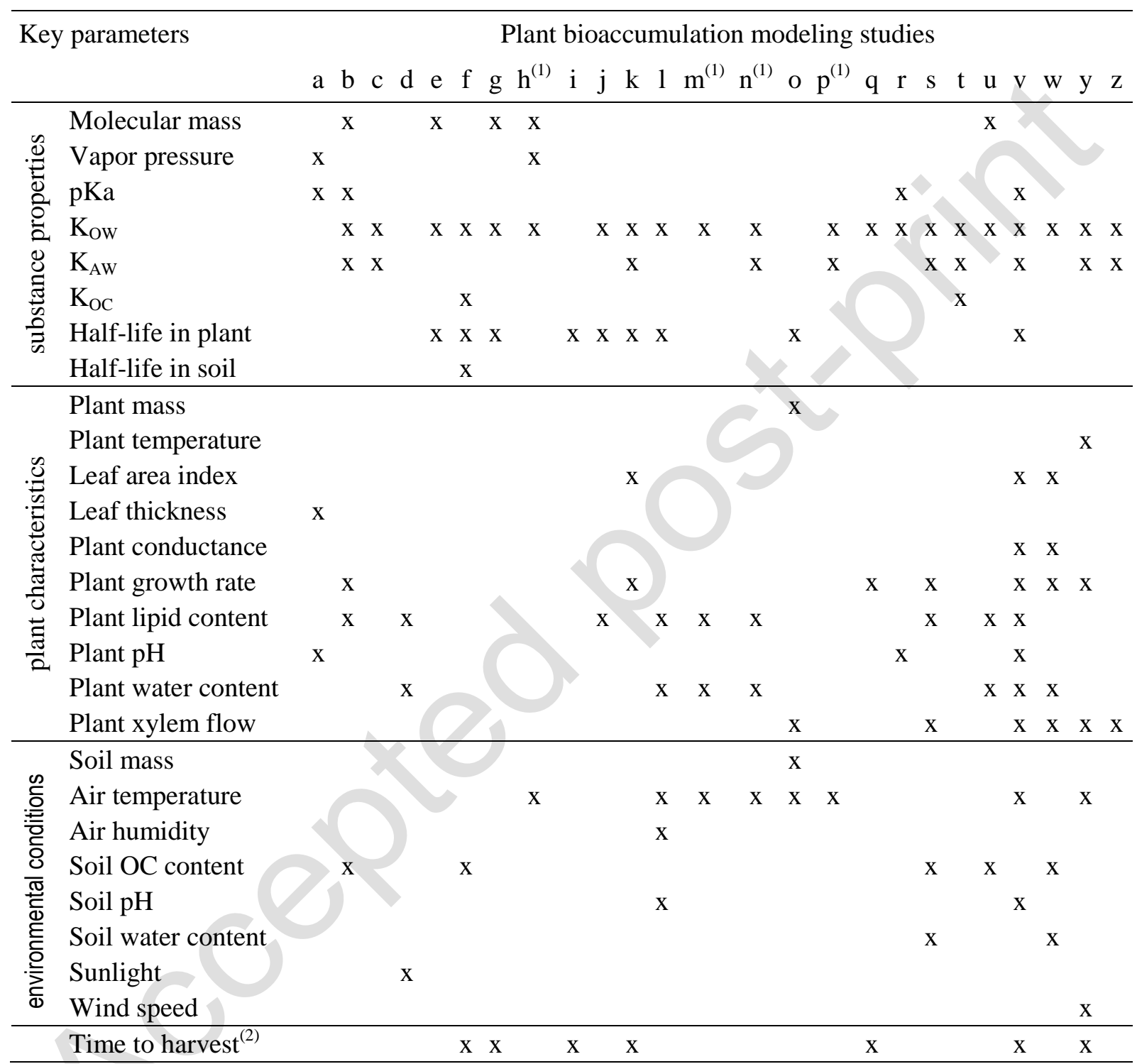

${ }^{\mathrm{a} B u c h h o l z}$ and Trapp (2015); ${ }^{\mathrm{b}}$ Collins et al. (2011); ${ }^{\mathrm{c}}$ Czub and McLachlan (2004); ${ }^{\mathrm{d}}$ Doucette

238 et al. (2005); ${ }^{\mathrm{e}}$ Fantke et al. (2011); ${ }^{\mathrm{f}}$ Fantke et al. (2012); ${ }^{\mathrm{g}}$ Fantke et al. (2013); ${ }^{\mathrm{h}}$ Fantke et al.

239 (2014); ${ }^{\mathrm{i}}$ Fantke and Jolliet (2016); ${ }^{\mathrm{j}}$ Fryer and Collins (2003); ${ }^{\mathrm{k}}$ Jacobsen et al. (2015); ${ }^{\mathrm{l} J u r a s k e}$

240 et al. (2008); ${ }^{\mathrm{m}} \mathrm{Kömp}$ and McLachlan (1997b); ${ }^{\mathrm{n}} \mathrm{Kömp}$ and McLachlan (1997a); ${ }^{\mathrm{o}}$ Legind et al.

241 (2011); ${ }^{\mathrm{p}}$ McLachlan (1995); ${ }^{\mathrm{q}}$ Rein et al. (2011); ${ }^{\mathrm{r}}$ Rendal et al. (2011); ${ }^{\mathrm{s}}$ Takaki et al. (2014);

$242{ }^{\mathrm{t}}$ Trapp et al. (1990); ${ }^{\mathrm{u}}$ Trapp et al. (2007); ${ }^{\mathrm{N}}$ Trapp and Legind (2011); ${ }^{\mathrm{W}}$ Trapp (2015);

$243{ }^{\mathrm{y}}$ Undeman et al. (2009); ${ }^{\mathrm{z}}$ Undeman and McLachlan (2011).

$244{ }^{1}$ Studies refer to "plant characteristics" in general as key aspect influencing bioaccumulation.

$245{ }^{2}$ Specific for chemicals applied in pulses to plants, such as pesticides. 
Not all data that are summarized in Table 2 as being relevant for bioaccumulation

248 models are commonly reported in experimental studies. We seek to identify and close gaps

249 between data provided by studies following current testing guidelines and data required for

250 improving plant bioaccumulation science by adapting current experimental methods (and

251 reporting requirements). In most cases these gaps can be addressed with minimal additional 252 resources.

\section{Current practice in plant bioaccumulation testing}

4.1. Reviews of experimental plant bioaccumulation studies

Experimental plant bioaccumulation tests are usually conducted under well-defined

environmental conditions (field and greenhouse studies) or under controlled conditions

(laboratory studies). Laboratory studies are usually carried out at $25^{\circ} \mathrm{C}$ and 14 hours light

cycle. Plants are exposed to known substance concentrations applied as a pulse or

continuously over a certain time period; one example of significant differences in exposure

design. Plants and the exposure media (soils or hydroponic solutions) are sampled at different

262 times during and after exposure, but at least once at the end of the experimental period.

263 Concentrations of contaminants are normally reported for plants and soil/hydroponic solution.

To highlight the state of science in experimental plant bioaccumulation testing, we

summarize key findings from two recent compilations of experimental data. The first

compilation focuses on plant bioaccumulation studies published in the peer-reviewed

267 literature for a broad range of chemical classes including PAHs, legacy pesticides, current use

268 pesticides (CUPs), PCBs, polybrominated diphenyl ethers (PBDEs), perfluorinated

compounds (PFCs), pharmaceutical and veterinary chemicals and others (Arnot et al., 2013).

This review focused on key words pertaining to quantitative metrics of plant bioaccumulation,

271 such as "bioconcentration factor" (BCF), "root concentration factor" (RCF), "transpiration

272 stream concentration factor" (TSCF), and other plant/exposure medium-based metrics as well 
as plant uptake and biotransformation rate constants. The resulting dataset includes 3,644 unique entries for 358 chemicals from 166 scientific references. Only 11 of the 166 studies included any mention of plant biotransformation and only 3 of the 11 included biotransformation rate information (for lindane and a series of phenols). Proximate composite analysis of the plants (i.e., lipid contents, water contents) was reported in only about $10 \%$ of all studies.

The second compilation focuses on experimentally derived pesticide dissipation halflives in plants obtained from key word searches with regard to "dissipation", "persistence" and "degradation" of pesticides in plants or certain plant components. This compilation identified 4,513 unique data points for 346 substances applied to almost 200 different plant species collected from 811 scientific references (Fantke and Juraske, 2013). Key points are to analyze the variability across substances, plant species and harvested plant components as well as to discuss different substance, vegetation and environmental aspects influencing pesticide dissipation kinetics. Only $18 \%$ of all reviewed references assessed one or more of these aspects, such as the influence of temperature on pesticide dissipation from plants. Furthermore, most reported data regarding substance (e.g. purity), plant characteristics (e.g. growth stage), application and sampling settings (e.g. treated plant components), and environmental conditions (e.g. air humidity) were incomplete (see Table 3 for an example).

\subsection{Limitations of reported data for use in bioaccumulation modeling}

Screening various experimental studies reveals there are few parameters that are consistently reported, such as the sampled plant component and the substance application rate (typically for pesticide treatment) or assumed exposure concentrations (typically for nonpesticide contaminants). In contrast, many parameters considered essential for interpreting experimental data and serving as important input for plant bioaccumulation models are infrequently reported, such as mean air temperature, substance fraction that is intercepted by 
plants or water content of the sampled plant components or soil characteristics. To

300 demonstrate differences in reporting data, we compared six studies that assessed the same

301 substance-plant species combination, namely cypermethrin applied to eggplant, and analyzed

302 residues in the same sampled plant components, i.e. eggplant fruits (Arora, 2009; Kaur et al.,

303 2011; Lu, 2011; Mukherjee et al., 2012; Sinha and Gopal, 2002; Walia et al., 2010). Data

304 reported in each of the compared studies are summarized in Table 3.

306 Table 3 Comparison of data reported in experimental plant bioaccumulation test studies

307 analyzing the same combination of chemical, plant species, and plant component, i.e.

308 cypermethrin residues measured in sampled eggplant fruits. For full parameter descriptions

309 see Table 4.

Parameter

Reported in experimental testing study

\begin{tabular}{|c|c|c|c|c|c|c|}
\hline & a & $b$ & $\mathrm{c}$ & $\mathrm{d}$ & $\mathrm{e}$ & $\mathrm{f}$ \\
\hline Study location(s) & $\checkmark^{1}$ & $\checkmark^{1}$ & $\checkmark^{1}$ & $\checkmark^{1}$ & $\checkmark^{1}$ & $\checkmark^{1}$ \\
\hline Study year(s) & & $\checkmark$ & & $\checkmark$ & & \\
\hline Study characteristics & $\checkmark$ & & $\checkmark$ & $\checkmark$ & & \\
\hline Application rate & $\checkmark$ & $\checkmark$ & $\checkmark$ & $\checkmark$ & $\checkmark$ & $\checkmark$ \\
\hline Application date (or days after planting) & & $\checkmark$ & & & & \\
\hline Application duration & & & & & $\checkmark$ & \\
\hline Application type & $\checkmark^{2}$ & $\checkmark^{2}$ & $\checkmark^{2}$ & $\checkmark^{2}$ & & $\checkmark^{2}$ \\
\hline Treated component & & & $\checkmark$ & & & \\
\hline Formulation & $\checkmark$ & $\checkmark$ & $\checkmark$ & $\checkmark$ & & $\checkmark$ \\
\hline Substance purity & $\checkmark$ & & $\checkmark$ & & & $\checkmark$ \\
\hline Relative air humidity & $\checkmark$ & $\checkmark$ & & & & \\
\hline Rain rate & $\checkmark^{3}$ & $\checkmark$ & & & & \\
\hline Wind speed & & $\checkmark$ & & & & \\
\hline Air temperature & $\checkmark$ & $\checkmark$ & & & & \\
\hline Binomial plant name (including variety) & $\checkmark$ & $\checkmark$ & $\checkmark$ & $\checkmark$ & $\mathfrak{\checkmark}^{4}$ & $\checkmark$ \\
\hline Plant growth period & & $\checkmark$ & & $\checkmark$ & & \\
\hline Plant stage & $\checkmark$ & & & $\checkmark$ & & $\checkmark$ \\
\hline Planting density & $\checkmark$ & $\checkmark$ & & & & \\
\hline Sampled component & $\checkmark$ & $\checkmark$ & $\checkmark$ & $\checkmark$ & $\checkmark$ & $\checkmark$ \\
\hline Sampled mass & $\checkmark$ & $\checkmark$ & $\checkmark$ & $\checkmark$ & $\checkmark$ & $\checkmark$ \\
\hline Sampling date(s)/time(s) & $\checkmark$ & $\checkmark$ & $\checkmark$ & $\checkmark$ & & $\checkmark$ \\
\hline Sampling specifics & $\checkmark$ & & $\checkmark$ & $\checkmark$ & $\checkmark$ & $\checkmark$ \\
\hline Residue analysis setup & $\mathfrak{\checkmark}^{5}$ & $\checkmark$ & $\checkmark$ & $\checkmark^{5}$ & $\checkmark$ & $\mathfrak{V}^{5}$ \\
\hline Analysis temperature(s) & $\checkmark$ & $\checkmark$ & $\checkmark$ & $\checkmark$ & & $\checkmark$ \\
\hline
\end{tabular}




\begin{tabular}{lcccccc} 
& a & b & c & d & e & f \\
\hline Solvents used & $\checkmark$ & $\checkmark$ & $\checkmark$ & $\checkmark$ & $\checkmark$ & $\checkmark$ \\
Fate processes studied & & & $\checkmark$ & $\checkmark$ & $\checkmark$ & \\
Kinetic models used & $\checkmark$ & & & & & $\checkmark$ \\
\hline
\end{tabular}

${ }^{\mathrm{a}}$ Sinha and Gopal (2002); ${ }^{\mathrm{b}}$ Arora (2009); ${ }^{\mathrm{c}} \mathrm{W}$ alia et al. (2010); ${ }^{\mathrm{d}}$ Kaur et al. (2011); ${ }^{\mathrm{e}} \mathrm{Lu}(2011)$;

$311{ }^{\mathrm{f}}$ Mukherjee et al. (2012).

$312{ }^{1}$ Reported in a way that does not allow deriving exact geographical coordinates; ${ }^{2}$ Application

313 height not given; ${ }^{3}$ Total rainfall $(\mathrm{mm})$ during experiment given, but explicit duration of

314 experiment not stated; ${ }^{4}$ Variety not given; ${ }^{5}$ Analytical limits of detection not given.

Many aspects of the sampling and analysis methods are reported by all studies

compared in Table 3. In contrast, several key parameters considered as important input to

plant bioaccumulation models and required by existing testing guidelines, are not consistently

reported (e.g. pesticide application dates, treated plant components, air temperature and

relative humidity, plant growth stage during treatment and at sampling times), or not reported

by any study (e.g. substance CAS number, $\mathrm{pH}$ of soil or hydroponic solution, plant root to

shoot ratio, plant leaf area index). Inconsistent collection or presentation of data makes it

difficult to use or compare results from different studies. For non-pesticide chemicals, there

are generally even less data reported, because testing requirements are less stringent (Arnot et

al., 2013). The inconsistency of key bioaccumulation information reported in the literature is

primarily because studies either do not follow any official guideline or they do not comply

with reporting recommendations when following existing guideline.

\section{Toward consistent bioaccumulation testing data sets}

\section{$330 \quad$ 5.1. Sampled plant components}

With respect to harvested plant samples, most modeling approaches either require

332 information on individual plant components, such as leaves, fruits, roots, etc. (Fantke et al.,

333 2011; Trapp and Legind, 2011), or specific component parts or tissues like fruit peel, fruit

334 pulp, epicuticular wax, nectar, etc. (Satchivi et al., 2006). In contrast, composite plant parts 
(straw, shoot, etc.) are often mixed and homogenized before analysis, thus assigning chemical quantities in individual interconnected components is usually impossible. The best case scenario is when sampled plant components are well distinguished and terms like "rind" or "fruit-surface" are avoided as these are difficult to allocate to specific plant components. As an example of good practice, using "bark" or "peel" are unambiguous terms referring to specific plant components.

To get the maximum benefit from an experimental study, we recommend to separately sample and report plant components and to provide a description of each sampled component. However, when facing sample mass limitations, i.e. not enough mass of specific components or tissue is sampled to allow a proper analysis, the reporting focus should be on the tissue or component that is most relevant for subsequent exposure studies, such as fruits harvested for human or animal consumption. This would require consistently describing each sampled component in terms of sampled mass and composition (e.g. water content). Moreover, we recommend reporting not only the day of sampling, but also the day of planting or at least the different plant component growth stages at sampling time, such as flowering. This does not require additional equipment, but provides important information about for example growth dilution.

\subsection{Considered (fate) processes}

Most experimental studies measure overall dissipation from plant samples (Braun et al., 1980; Galietta et al., 2011; Lee and Cheng, 1983; Willis and McDowell, 1987) or focus on particular dissipation processes, such as volatilization (Bedos et al., 2010; Guth et al., 2004; Kubiak et al., 1995; Stork et al., 1998), photodecomposition (Burrows et al., 2002; Katagi, 2004; McCrady and Maggard, 1993) or microbial degradation (Azaizeh et al., 2011; Quistad et al., 1974; Roy et al., 2001). However, whereas this might be sufficient to ensure compliance with regulatory thresholds for plant uptake and bioaccumulation, it does not help 
to understand bioaccumulation mechanisms as relevant in other science-policy fields.

362 Moreover, mechanistic models typically rely on information of all contributing dissipation processes to arrive at a complete set of rate coefficients as input (Fantke et al., 2014). Such

364 processes include dry and wet deposition, advective root and foliar uptake, volatilization (gas365 exchange), wash-off from plant surfaces, chemical concentration dilution due to plant growth, 366 direct and indirect photolysis, microbiological, chemical and photodecomposition,

367 metabolism due to hydroxylation and oxidation, and plant-internal translocation in xylem and 368 phloem (Collins et al., 2011; Fantke and Juraske, 2013). It is often impractical to

369 simultaneously report rate constants for various individual dissipation processes. However, if 370 this information is reported, it allows for a much more detailed analysis and understanding of 371 the dynamics of chemicals in the plant-environment systems relevant for different science372 policy fields. We recommend reporting rate constants for specific processes whenever possible, e.g.

374 for biodegradation when metabolites are known based on metabolite concentrations or for 375 volatilization based on measuring air concentrations. When only overall dissipation can be 376 reported, we recommend testing different kinetic models instead of simply assuming first377 order kinetics for best interpretability of actual dissipation. While reporting data for specific 378 processes may require additional equipment (e.g. when sampling air), testing different kinetic

379 models can easily be implemented without additional costs, and an overview of different 380 kinetic models is for example given in Fantke and Juraske (2013). Further, we recommend 381 reporting environmental conditions to the extent feasible. This includes most importantly air 382 temperature, air humidity, and soil properties like $\mathrm{pH}$ and organic carbon content. If air 383 temperature cannot be measured directly, average temperature over the study duration at the 384 study site can serve as proxy, and if air humidity is not available, recording the number of rain 385 events can serve as alternative. 
Partitioning of neutral organic chemicals is predominantly controlled by the quantity and quality of organic carbon; hence, organic carbon content of the soil can contribute to variance in the plant bioaccumulation of neutral organics exposed from soils (Seth et al., 1999). While analyzing soil samples for carbon content might come at the expense of additional resources, classifying the soil (e.g. as podzol) and providing a basic description of

391 the soil horizons will already give some information about potential soil characteristics.

392 Quantifying the environmental fate and sorption of ionizable organic chemicals is generally more uncertain. Evidence suggests that the cation exchange capacity (CEC) of the soil is a key determinant for the sorption of cations (Droge and Goss, 2013). For anionic chemicals, the sorption to soils may be adequately characterized by soil organic carbon and soil $\mathrm{pH}$ (Kah and Brown, 2007). At present, we recommend reporting CEC for soil exposures to cations.

397 Revisions to guidelines and reporting requirements for plant bioaccumulation for ionizable organic chemicals should consider the emerging science on chemical distribution of these chemicals in multimedia environments.

Finally, bioaccumulation processes are usually chemical-specific and, hence, physicochemical properties need to be considered in modeling approaches. However, most if not all relevant chemical data are already reported elsewhere, e.g. in the database on registered substances of the European Chemicals Agency (http://echa.europa.eu/informationon-chemicals), except the CAS registry number that is essential to identify a chemical unambiguously. We hence recommend to at least reporting CAS registry numbers.

\subsection{Recommendations for reported bioaccumulation testing data} Based on the findings of our review of experimental plant bioaccumulation testing

409 studies and our knowledge regarding bioaccumulation models, we present a set of 410 recommended parameters to be included in future testing studies (Table 4). Parameters that 411 have been identified being of high relevance for interpreting test results and for developing 
412 plant bioaccumulation models are specified in the "priority data list" of Table 4. Parameters

413 providing additional information for interpreting experimental results and for use in

414 bioaccumulation modeling are given in the "complementary data list" of Table 4.

416 Table 4 Priority and complementary data recommended to be reported in testing studies

417 referring to parameters relevant to improve the interpretation of measured data and to support

418 quantification of bioaccumulation in plants with modeling approaches.

\begin{tabular}{|c|c|}
\hline Parameter (unit) & Description \\
\hline \multicolumn{2}{|c|}{ PRIORITY DATA LIST (recommended to be reported by all testing studies) } \\
\hline CAS-RN & $\begin{array}{l}\text { Chemical Abstracts Service Registry Number; unique identifier of a } \\
\text { tested chemical }\end{array}$ \\
\hline Study location(s) & $\begin{array}{l}\text { Location (geographic coordinates) or city/specific area within } \\
\text { country) of experimental study site(s) }\end{array}$ \\
\hline Study characteristics & Specific conditions, such as field or greenhouse study \\
\hline $\begin{array}{l}\text { Application or release } \\
\text { rate }\left(\mathrm{kg} \mathrm{day}^{-1} \text { or }\right. \\
\left.\mathrm{L} \mathrm{ha}^{-1} \mathrm{day}^{-1}\right)\end{array}$ & $\begin{array}{l}\text { Application or release rate of chemical; number of applications } \\
\text { during study }\end{array}$ \\
\hline $\begin{array}{l}\text { Application or release } \\
\text { date(s) }\end{array}$ & $\begin{array}{l}\text { For purposely applied chemicals (e.g. pesticides), application or } \\
\text { release date(s) of chemical (exposure time of the plant) or } \\
\text { application or release in days after planting; for single exposure } \\
\text { events (e.g. spill), exposure concentration and duration }\end{array}$ \\
\hline $\begin{array}{l}\text { Treated plant } \\
\text { component(s) or } \\
\text { exposure medium }\end{array}$ & $\begin{array}{l}\text { Treated (exposed) plant component (leaf, pulp, etc.) or } \\
\text { environmental compartment/matrix (soil, hydroponic solution, etc.) }\end{array}$ \\
\hline Formulation (\%) & $\begin{array}{l}\text { Fraction of applied or released substance/active ingredient, if } \\
\text { applied or released as formulation (e.g. refers to active ingredient of } \\
\text { interest plant protection product formulation) }\end{array}$ \\
\hline Air temperature $\left({ }^{\circ} \mathrm{C}\right)$ & $\begin{array}{l}\text { Mean daily temperature in air (at soil surface level) and min/max } \\
\text { range }\end{array}$ \\
\hline Soil pH & $\mathrm{pH}$ of treated/exposed/sampled soil \\
\hline $\begin{array}{l}\text { Soil OC content } \\
\left(\mathrm{kg} \mathrm{kg}^{-1}\right)\end{array}$ & $\begin{array}{l}\text { Organic carbon content in treated/exposed/sampled soil for neutral } \\
\text { organic chemicals; alternatively, the soil type and horizons can be } \\
\text { described }\end{array}$ \\
\hline Soil CEC (meq $\mathrm{g}^{-1}$ ) & $\begin{array}{l}\text { Cation exchange capacity of treated/exposed/sampled soil for } \\
\text { ionizable organic chemicals }\end{array}$ \\
\hline Binomial plant name & $\begin{array}{l}\text { Unambiguous identification of plant species and, if required, variety } \\
\text { or cultivar }\end{array}$ \\
\hline
\end{tabular}




\begin{tabular}{|c|c|}
\hline Parameter (unit) & Description \\
\hline Plant stage & $\begin{array}{l}\text { Growth stage of the treated/exposed/sampled plant (mature, } \\
\text { seedling, etc.) }\end{array}$ \\
\hline Capture coefficient $(-)$ & $\begin{array}{l}\text { Substance capture coefficient as average substance fraction that is } \\
\text { intercepted by plant during sampling period and } \mathrm{min} / \mathrm{max} \text { range }\end{array}$ \\
\hline $\begin{array}{l}\text { Plant transpiration } \\
\left(\mathrm{L} \mathrm{kg}^{-1} \text { or } \mathrm{Lday}^{-1}\right)\end{array}$ & $\begin{array}{l}\text { Plant transpiration as inverse of weight unit of plant dry mass } \\
\text { produced per weight unit of consumed water or as volumetric } \\
\text { transpiration stream per time unit }\end{array}$ \\
\hline Sampled component(s) & $\begin{array}{l}\text { Sampled plant component(s) (leaf, pulp, etc.) or tissue(s) (wax } \\
\text { layer, etc.) and proximate composition (lipids, organic carbon, } \\
\text { carbohydrates, water) }\end{array}$ \\
\hline Sampled mass $(\mathrm{kg})$ & Dry and/or wet mass of plant sample(s) \\
\hline $\begin{array}{l}\text { Sampling } \\
\text { date(s)/time(s) }\end{array}$ & $\begin{array}{l}\text { Sampling date(s) or sampling days or times after application or } \\
\text { release or exposure (day) }\end{array}$ \\
\hline Sampling specifics & $\begin{array}{l}\text { Specific sampling conditions, such as cold storage, washing or food } \\
\text { processing after harvest/sampling }\end{array}$ \\
\hline Fate processes studied & $\begin{array}{l}\text { Considered fate processes (including post-harvest) either } \\
\text { contributing to bioaccumulation (penetration, deposition, etc.) or } \\
\text { biodilution (volatilization, metabolism, etc.) }\end{array}$ \\
\hline Kinetic models used & $\begin{array}{l}\text { Applied assessment models in case of calculating rate coefficients } \\
\text { (pseudo-first order, second order, biexponential, etc.); this is only } \\
\text { required if the underlying raw data (e.g. concentration at any } \\
\text { sampled time) is not provided }\end{array}$ \\
\hline
\end{tabular}

COMPLEMENTARY DATA LIST (recommended to be reported when feasible)

\begin{tabular}{|c|c|}
\hline Study year(s) & Year(s) of experimental study \\
\hline $\mathrm{M}\left(\mathrm{g} \mathrm{mol}^{-1}\right)$ & Molecular mass \\
\hline $\log \mathrm{K}_{\mathrm{AW}}(-)$ & $\begin{array}{l}\text { Air/water partition coefficient; alternatively, the Henry's law } \\
\text { constant }\left(\mathrm{Pa} \mathrm{m} \mathrm{mol}^{-1}\right) \text {, or the combination of saturation vapor } \\
\text { pressure }(\mathrm{Pa}) \text { and water solubility }\left(\mathrm{g} \mathrm{m}^{-3}\right)\end{array}$ \\
\hline $\log \mathrm{K}_{\mathrm{OW}}(-)$ & $\mathrm{N}$-octanol/water partition coefficient \\
\hline $\log \mathrm{K}_{\mathrm{OA}}(-)$ & $\begin{array}{l}N \text {-octanol/air partition coefficient; alternatively, Koa can be } \\
\text { calculated from Kaw and Kow as } \log \text { Koa }=\log \text { Kow }-\log \text { Kaw }\end{array}$ \\
\hline $\mathrm{K}_{\mathrm{OC}}\left(\mathrm{L} \mathrm{kg}^{-1}\right)$ & Organic carbon normalized soil sorption coefficient \\
\hline $\mathrm{pKa}(-)$ & Acid dissociation constant \\
\hline Chiral configuration & Specification of $(S)-(+)$-enantiomer and $(R)-(-)$-enantiomer status \\
\hline $\begin{array}{l}\text { Application or release } \\
\text { duration (day) }\end{array}$ & $\begin{array}{l}\text { Application or release duration of chemical (exposure duration of } \\
\text { the plant) }\end{array}$ \\
\hline $\begin{array}{l}\text { Application or release } \\
\text { type }\end{array}$ & $\begin{array}{l}\text { Application or release type or method (for pesticides aerial spray, } \\
\text { drip irrigation, soil injection, etc.) including release or application } \\
\text { height }(\mathrm{m})\end{array}$ \\
\hline
\end{tabular}




\begin{tabular}{|c|c|}
\hline Parameter (unit) & Description \\
\hline Substance purity (\%) & $\begin{array}{l}\text { Purity of chemical analytical standard or substance/active ingredient } \\
\text { as part of mixture; radio purity, if applicable }\end{array}$ \\
\hline Rain rate $\left(\mathrm{mm} \mathrm{day}^{-1}\right)$ & $\begin{array}{l}\text { Daily average precipitation rate }\left(1 \mathrm{~mm}=1 \mathrm{~L} \mathrm{~m}^{-2}\right) \text { and } \mathrm{min} / \mathrm{max} \\
\text { range; alternatively, average relative air humidity or number of rain } \\
\text { events over the study duration can be reported }\end{array}$ \\
\hline Wind speed $\left(\mathrm{m} \mathrm{day}^{-1}\right)$ & Mean wind speed at $2 \mathrm{~m}$ above soil surface level and $\mathrm{min} / \mathrm{max}$ range \\
\hline Soil temperature $\left({ }^{\circ} \mathrm{C}\right)$ & Mean temperature of treated/exposed/sampled soil \\
\hline $\begin{array}{l}\text { Soil water content } \\
\left(\mathrm{L} \mathrm{L}^{-1}\right)\end{array}$ & Fraction of volumetric water in bulk soil \\
\hline Soil porosity $\left(\mathrm{LL}^{-1}\right)$ & $\begin{array}{l}\text { Volumetric porosity in soil or fraction of volumetric pores in bulk } \\
\text { soil }\end{array}$ \\
\hline $\begin{array}{l}\text { Plant growth rates } \\
\left(\text { day }^{-1}\right)\end{array}$ & $\begin{array}{l}\text { Plant growth rates for different plant components the differences in } \\
\text { plant component masses }(\mathrm{kg}) \text { per time period(s) during the study } \\
\text { (day) }\end{array}$ \\
\hline $\begin{array}{l}\text { Planting density } \\
\left(n_{\text {plants }} \mathrm{ha}^{-1}\right)\end{array}$ & $\begin{array}{l}\text { Number of plants grown per defined area (only in field and } \\
\text { greenhouse studies) }\end{array}$ \\
\hline Root to shoot ratio $(-)$ & Average ratio between below-ground and aerial plant components \\
\hline Leaf fraction $(-)$ & Average fraction of aerial plant components that is leaf \\
\hline Fruit fraction $(-)$ & Average fraction of aerial plant components that is fruit \\
\hline Stem fraction $(-)$ & Average fraction of aerial plant components that is stem/trunk \\
\hline LAI $(-)$ & $\begin{array}{l}\text { Leaf area index at different times between substance application or } \\
\text { release and plant harvest/sampling; for plants with only } 1 \text { leaf layer } \\
\text { the leaf cover }\left(\mathrm{m}^{-2}\right) \text { can be reported instead }\end{array}$ \\
\hline $\begin{array}{l}\text { Leaf/fruit/stem/root } \\
\text { water }\left(\mathrm{L} \mathrm{kg}^{-1}\right)\end{array}$ & Average water content of plant leaf/fruit/stem/root \\
\hline $\begin{array}{l}\text { Leaf/fruit/stem/root } \\
\text { lipid }\left(\mathrm{L} \mathrm{kg}^{-1}\right)\end{array}$ & Average lipid content of plant leaf/fruit/stem/root \\
\hline Stem height $(\mathrm{m})$ & Average height of plant stem/trunk during study period \\
\hline Residue analysis setup & $\begin{array}{l}\text { Description of all post-sampling procedures and analysis steps } \\
\text { including durations of individual processing and analysis steps and } \\
\text { analytical detection limits }\end{array}$ \\
\hline $\begin{array}{l}\text { Analysis temperature }(\mathrm{s}) \\
\left({ }^{\circ} \mathrm{C}\right)\end{array}$ & Temperatures at all post-sampling processing and analysis stages \\
\hline Solvents used & $\begin{array}{l}\text { Solvents and solvent concentrations/purity used at all post-sampling } \\
\text { processing and analysis stages }\end{array}$ \\
\hline
\end{tabular}




\section{Conclusions and implications for future research and policy making}

We have highlighted current data gaps that need to be addressed to improve the quantitative understanding of organic chemical bioaccumulation and biotransformation in plants. For non-organic contaminants, the reader is referred to the respective literature (Pulford and Watson, 2003; Raskin and Ensley, 2000; Salt et al., 1995; Weis and Weis, 2004).

We emphasize the key experimental parameters that would need to be measured and reported in priority and without much additional effort or equipment in order to improve models for use in various regulatory and decision support contexts. The focus is on terrestrial plants, but similar concepts should also be considered for aquatic plants.

Our reporting recommendations (Table 4) are intended to optimize existing testing guidelines for improved mechanistic bioaccumulation knowledge in a cost-effective manner.

431 This includes reducing unnecessary or redundant testing of the same chemical-plant combinations and to keep study areas and sampling mass reasonably small. Ultimately, the focus of future experimental testing should be to improve data quality and to better facilitate the interpretation and use of testing study results in decision support models.

Acknowledgements

This work was financially supported by the Marie Curie project Quan-Tox (grant agreement no. 631910) funded by the European Commission under the Seventh Framework

Programme.

\section{References}

442 Arnot, J.A., Shunthirasingham, C., Dettenmaier, E., Doucette, B., Mackay, D., 2013.

443 Measured plant bioaccumulation data and screening-level models for organic chemicals, 444 Society of Environmental Toxicology and Chemistry Europe 23rd Annual Meeting, 12-16 445 May, 2013, Glasgow, Scotland, p. 286.

446 Arora, S., 2009. Analysis of insecticides in okra and brinjal from IPM and non-IPM fields. 447 Environ. Monit. Assess. 151, 311-315. 
Azaizeh, H., Castro, P.M.L., Kidd, P., 2011. Biodegradation of organic xenobiotic pollutants in the rhizosphere, in: Schröder, P., Collins, C.D. (Eds.), Organic Xenobiotics and Plants: From Mode of Action to Ecophysiology. Springer Press, Dordrecht, pp. 191-215.

Bacci, E., Calamari, D., Gaggi, C., Vighi, M., 1990. Bioconcentration of organic chemical vapors in plant leaves: experimental measurements and correlation. Environ. Sci. Technol. 24, 885-889.

Bedos, C., Rousseau-Djabri, M.-F., Loubet, B., Durand, B., Flura, D., Briand, O., Barriuso, E., 2010. Fungicide volatilization measurements: Inverse modeling, role of vapor pressure, and state of foliar residue. Environ. Sci. Technol. 44, 2522-2528.

Braun, H.E., Ritcey, G.M., Frank, R., McEwen, F.L., Ripley, B.D., 1980. Dissipation rates of insecticides in six minor vegetable crops grown on organic soils in Ontario, Canada. Pestic. Sci. 11, 605-616.

Buchholz, A., Trapp, S., 2015. How active ingredient localisation in plant tissues determines the targeted pest spectrum of different chemistries. Pest Manage. Sci., doi:10.1002/ps.4070.

Burrows, H.D., Canle L., M., Santaballa, J.A., Steenken, S., 2002. Reaction pathways and mechanisms of photodegradation of pesticides. J. Photochem. Photobiol. 67, 71-108.

Calamari, D., 1993. Chemical Exposure Predictions. CRC Press, Taylor and Francis Group,

Collins, C., Fryer, M., Grosso, A., 2006. Plant uptake of non-ionic organic chemicals.

Collins, C.D., Martin, I., Doucette, W., 2011. Plant uptake of xenobiotics, in: Schröder, P.,

Cousins, I.T., Mackay, D., 2001. Strategies for including vegetation compartments in multimedia models. Chemosphere 44, 643-654.

Czub, G., McLachlan, M.S., 2004. Bioaccumulation potential of persistent organic chemicals

Doucette, W.J., Chard, J.K., Moore, B.J., Staudt, W.J., Headley, J.V., 2005. Uptake of sulfolane and diisopropanolamine (DIPA) by cattails (Typha latifolia). Microchem. J. 81, 4149.

Droge, S.T.J., Goss, K.-U., 2013. Sorption of organic cations to phyllosilicate clay minerals: CEC-normalization, salt dependency, and the role of electrostatic and hydrophobic effects. Environ. Sci. Technol. 47, 14224-14232.

EC, 1998. Directive 98/8/EC of the European Parliament and of the Council of 16 February 1998 concerning the placing of biocidal products on the market. Commission of the European Communities, Brussels.

484 EC, 2006. Regulation (EC) No 1907/2006 of the European Parliament and of the Council of 48518 December 2006 concerning the Registration, Evaluation, Authorisation and Restriction of 486 Chemicals (REACH). Commission of the European Communities, Brussels. 
EC, 2009. Regulation (EC) No 1107/2009 of the European Parliament and of the Council of 21 October 2009 concerning the placing of plant protection products on the market and repealing Council Directives 79/117/EEC and 91/414/EEC. Commission of the European Communities, Brussels.

EFSA, 2010. Standard sample description for food and feed. European Food Safety Authority. EFSA Journal 2010; 8(1): 1457, Parma.

EFSA, 2012. Use of the EFSA standard sample description for the reporting of data on the control of pesticide residues in food and feed according to Regulation (EC) No 396/2005. European Food Safety Authority, EFSA Journal 2012; 10(3): 2628, Parma.

EFSA, 2013. Use of the EFSA standard sample description for the reporting of data on the control of pesticide residues in food and feed according to Regulation (EC) No 396/2005 (revision 1). European Food Safety Authority, EFSA Journal 2013; 11(1): 3076, Parma.

EFSA, 2014a. EFSA guidance document for evaluating laboratory and field dissipation studies to obtain DegT50 values of active substances of plant protection products and transformation products of these active substances in soil. European Food Safety Authority. EFSA Journal 2014; 12(5): 3662, Parma.

EFSA, 2014b. Use of the EFSA standard sample description (SSD) for the reporting of data on the control of pesticide residues in food and feed according to Regulation (EC) No 396/2005 (Version: 2013 data collection). European Food Safety Authority. EFSA Journal 2014; 12(1): 3545, Parma.

Eggen, T., Asp, T.N., Grave, K., Hormazabal, V., 2011. Uptake and translocation of metformin, ciprofloxacin and narasin in forage- and crop plants. Chemosphere 85, 26-33.

Environment Agency, 2006. Evaluation of models for predicting plant uptake of chemicals from soil, Report SC050021/SR. Environment Agency, Bristol.

EU RLRP, 2011. SANCO/12495/2011: Method validation \& quality control procedures for pesticide residues analysis in food \& feed. EU Reference Laboratories for Residues of Pesticides, Brussels.

EU RLRP, 2013. SANCO/12571/2013: Guidance document on analytical quality control and validation procedures for pesticide residues analysis in food and feed. EU Reference Laboratories for Residues of Pesticides, Brussels.

Fantke, P., Charles, R., de Alencastro, L.F., Friedrich, R., Jolliet, O., 2011. Plant uptake of pesticides and human health: Dynamic modeling of residues in wheat and ingestion intake. Chemosphere 85, 1639-1647.

Fantke, P., Gillespie, B., Juraske, R., Jolliet, O., 2014. Estimating half-lives for pesticide dissipation from plants. Environ. Sci. Technol. 48, 8588-8602.

Fantke, P., Jolliet, O., 2016. Life cycle human health impacts of 875 pesticides. Int. J. Life Cycle Assess. 21, 722-733.

Fantke, P., Juraske, R., 2013. Variability of pesticide dissipation half-lives in plants. Environ. Sci. Technol. 47, 3548-3562. 
Fantke, P., Wieland, P., Juraske, R., Shaddick, G., Sevigné, E., Friedrich, R., Jolliet, O., 2012. Parameterization models for pesticide exposure via crop consumption. Environ. Sci. Technol. 46, 12864-12872.

529 Fantke, P., Wieland, P., Wannaz, C., Friedrich, R., Jolliet, O., 2013. Dynamics of pesticide 530 uptake into plants: From system functioning to parsimonious modeling. Environ. Modell.

531 Softw. 40, 316-324.

532 Fryer, M.E., Collins, C.D., 2003. Model intercomparison for the uptake of organic chemicals by plants. Environ. Sci. Technol. 37, 1617-1624.

Galietta, G., Egaña, E., Gemelli, F., Maeso, D., Casco, N., Conde, P., Nueñz, S., 2011. Pesticide dissipation curves in peach, pear and tomato crops in Uruguay. J. Environ. Sci. Heal. 46, 35-40.

Gobas, F.A.P.C., Burkhard, L.P., Doucette, W.J., Sappington, K.G., Verbruggen, E.M.J., Hope, B.K., Bonnell, M.A., Arnot, J.A., Tarazona, J.V., 2016. Review of existing terrestrial bioaccumulation models and terrestrial bioaccumulation modeling needs for organic chemicals. Integr. Environ. Assess. Manage. 12, 123-134.

541 Guth, J.A., Reischmann, F.J., Allen, R., Arnold, D., Hassink, J., Leake, C.R., Skidmore, M.W., Reeves, G.L., 2004. Volatilisation of crop protection chemicals from crop and soil surfaces under controlled conditions - prediction of volatile losses from physico-chemical properties. Chemosphere 57, 871-887.

Houghton, R.A., Hall, F., Goetz, S.J., 2009. Importance of biomass in the global carbon cycle. J. Geophys. Res. 114, G00E03.

ITRC, 2011. Incorporating bioavailability considerations into the evaluation of contaminated sediment sites. Interstate Technology and Regulatory Council, Washington, D.C.

549 Jacobsen, R.E., Fantke, P., Trapp, S., 2015. Analysing half-lives for pesticide dissipation in plants. SAR QSAR Environ. Res. 26, 325-342.

Jones, K.C., Duarte-Davidson, R., 1997. Transfers of airborne PCDD/Fs to bulk deposition collectors and herbage. Environ. Sci. Technol. 37, 2937-2943.

Juraske, R., Antón, A., Castells, F., 2008. Estimating half-lives of pesticides in/on vegetation for use in multimedia fate and exposure models. Chemosphere 70, 1748-1755.

Kah, M., Brown, C.D., 2007. Prediction of the adsorption of ionizable pesticides in soils. J.

556 Agr. Food Chem. 55, 2312-2322.

557 Katagi, T., 2004. Photodegradation of pesticides on plant and soil surfaces. Rev. Environ.

558 Contam. T. 182, 1-195.

559 Kaur, P., Yadav, G.S., Chauhan, R., Kumari, B., 2011. Persistence of cypermethrin and 560 decamethrin residues in/on brinjal fruits. B. Environ. Contam. Tox. 87, 693-698.

561 Kömp, P., McLachlan, M.S., 1997a. Influence of temperature on the plant/air partitioning of 562 semivolatile organic compounds. Environ. Sci. Technol. 31, 886-890. 
Kömp, P., McLachlan, M.S., 1997b. Interspecies variability of the plant/air partitioning of 564 polychlorinated biphenyls. Environ. Sci. Technol. 31, 2944-2948.

Kubiak, R., Muller, T., Maurer, T., Eichhorn, K.W., 1995. Volatilization of pesticides from plant and soil surfaces - Field versus laboratory experiments. Int. J. Environ. An. Ch. 58, 349358.

Lee, W., Cheng, E.Y., 1983. A systematical study of insecticides residues on vegetables, I. The influences of plant varieties on the deposition and dissipation of insecticides. J. Agric. Res. China 32, 292-302. model applied for drip irrigation of an insecticide to pepper fruit plants. Pest Manag. Sci. 67, 521-527. tetrachlorobiphenyl by whole plants-poplars and switchgrass. Environ. Sci. Technol. 43, 7503-7509.

Lu, J.L., 2011. Insecticide residues in eggplant fruits, soil, and water in the largest eggplantproducing area in the Philippines. Water Air Soil Pollut. 220, 413-422.

Macherius, A., Eggen, T., Lorenz, W., Moeder, M., Ondruschka, J., Reemtsma, T., 2012. Metabolization of the bacteriostatic agent triclosan in edible plants and its consequences for plant uptake assessment. Environ. Sci. Technol. 46, 10797-10804. tetrachlorodibenzo-p-dioxin sorbed to grass foliage. Environ. Sci. Technol. 27, 343-350.

McKone, T.E., Maddalena, R.L., 2007. Plant uptake of organic pollutants from soil: Bioconcentration estimates based on models and experiments. Environ. Toxicol. Chem. 26, 2494-2504.

McLachlan, M.S., 1995. Bioaccumulation of hydrophobic chemicals in agricultural food chains. Environ. Sci. Technol. 30, 252-259.

589 Mikes, O., Cupr, P., Trapp, S., Klanova, J., 2009. Uptake of polychlorinated biphenyls and 590 organochlorine pesticides from soil and air into radishes (Raphanus sativus). Environ. Pollut. $591 \quad 157,488-496$.

592 Mukherjee, I., Kumar, A., Kumar, A., 2012. Persistence behavior of combination mix crop 593 protection agents in/on eggplant fruits. B. Environ. Contam. Tox. 88, 338-343.

594 OECD, 1992. OECD guidelines for the testing of chemicals, Section 3 degradation and accumulation, test no. 301: Ready biodegradability. Organisation for Economic Co-operation and Development, Paris.

597 OECD, 1997. OECD series on testing and assessment, No 9 - guidance document for the 598 conduct of studies of occupational exposure to pesticides during agricultural application. 599 Organisation for Economic Co-operation and Development, Paris. 
OECD, 2002. OECD guidelines for the testing of chemicals, Section 3 degradation and accumulation, test no. 307: Aerobic and anaerobic transformation in soil. Organisation for Economic Co-operation and Development, Paris.

OECD, 2006a. OECD guidelines for the testing of chemicals, Section 2 effects on biotic systems, test no. 208: Terrestrial plant test: Seedling emergence and seedling growth test. Organisation for Economic Co-operation and Development, Paris.

OECD, 2006b. OECD guidelines for the testing of chemicals, Section 2 effects on biotic systems, test no. 227: Terrestrial plant test: Vegetative vigour test. Organisation for Economic Co-operation and Development, Paris.

OECD, 2007a. OECD guidelines for the testing of chemicals, Section 5 other test guidelines, test no. 501: Metabolism in crops. Organisation for Economic Co-operation and 611 Development, Paris.

OECD, 2007b. OECD guidelines for the testing of chemicals, Section 5 other test guidelines, test no. 502: Metabolism in rotational crops. Organisation for Economic Co-operation and 614 Development, Paris.

OECD, 2007c. OECD guidelines for the testing of chemicals, Section 5 other test guidelines, test no. 504: Residues in rotational crops (limited field studies). Organisation for Economic Co-operation and Development, Paris.

OECD, 2007d. OECD guidelines for the testing of chemicals, Section 5 other test guidelines, test no. 506: Stability of pesticide residues in stored commodities. Organisation for Economic Co-operation and Development, Paris.

OECD, 2007e. OECD guidelines for the testing of chemicals, Section 5 other test guidelines, test no. 507: Nature of the pesticide residues in processed commodities - high temperature hydrolysis. Organisation for Economic Co-operation and Development, Paris.

OECD, 2008. OECD guidelines for the testing of chemicals, Section 5 other test guidelines, test no. 508: Magnitude of the pesticide residues in processed commodities. Organisation for Economic Co-operation and Development, Paris.

OECD, 2009. OECD guidelines for the testing of chemicals, Section 5 other test guidelines, 628 test no. 509: Crop field trial. Organisation for Economic Co-operation and Development, 629 Paris.

630 Pulford, I.D., Watson, C., 2003. Phytoremediation of heavy metal-contaminated land by trees - A review. Environ. Int. 29, 529-540.

632 Quistad, G.B., Staiger, L.E., Schooley, D.A., 1974. Environmental degradation of the insect growth regulator methoprene (isopropyl $(2 E, 4 E)$-11-methoxy-3,7,11-trimethyl-2,4-

635 Raskin, I., Ensley, B.D., 2000. Phytoremediation of Toxic Metals: Using Plants to Clean Up the Environment. John Wiley and Sons, New York.

637 Rein, A., Legind, C.N., Trapp, S., 2011. New concepts for dynamic plant uptake models. SAR 638 QSAR Environ. Res. 22, 191-215. 
Rendal, C., Kusk, K.O., Trapp, S., 2011. Optimal choice of pH for toxicity and

640 bioaccumulation studies of ionizing organic chemicals. Environ. Toxicol. Chem. 30, 2395-

6412406.

642 Riederer, M., 1990. Estimating partitioning and transport of organic chemicals in the

643 foliage/atmosphere system: Discussion of a fugacity-based model. Environ. Sci. Technol. 24, $644 \quad 829-837$.

645 Roy, J.W., Hall, J.C., Parkin, G.W., Wagner-Riddle, C., Clegg, B.S., 2001. Seasonal leaching 646 and biodegradation of dicamba in turfgrass. J. Environ. Qual. 30, 1360-1370.

647 Salt, D.E., Blaylock, M., Kumar, N.P.B.A., Dushenkov, V., Ensley, B.D., Chet, I., Raskin, I., 648 1995. Phytoremediation: A novel strategy for the removal of toxic metals from the 649 environment using plants. Nat. Biotechnol. 13, 468-474.

650 Samsøe-Petersen, L., Larsen, E.H., Larsen, P.B., Bruun, P., 2002. Uptake of trace elements 651 and PAHs by fruit and vegetables from contaminated soils. Environ. Sci. Technol. 36, 30576523063.

653 Satchivi, N.M., Stoller, E.W., Wax, L.M., Briskin, D.P., 2006. A nonlinear, dynamic, 654 simulation model for transport, and whole plant allocation of systemic xenobiotics following 655 foliar application. Pestic. Biochem. Phys. 84, 83-97.

656 Scheunert, I., Topp, E., Attar, A., Korte, F., 1994. Uptake pathways of chlorobenzenes in 657 plants and their correlation with $n$-octanol/water partition coefficients. Ecotox. Environ. Safe. 658 27, 90-104.

659 Schreiber, L., Schönherr, J., 2009. Water and Solute Permeability of Plant Cuticles:

660 Measurement and Data Analysis. Springer Press, Berlin.

661 Schwitzguébel, J.-P., Page, V., Martins-Dias, S., Davies, L.C., Vasilyeva, G., Strijakova, E., 662 2011. Using plants to remove foreign compounds from contaminated water and soil, in: 663 Schröder, P., Collins, C.D. (Eds.), Organic Xenobiotics and Plants: From Mode of Action to 664 Ecophysiology. Springer Press, Dordrecht, pp. 149-189.

665 Seth, R., Mackay, D., Muncke, J., 1999. Estimating the organic carbon partition coefficient 666 and its variability for hydrophobic chemicals. Environ. Sci. Technol. 33, 2390-2394.

667 Sharma, M., McBean, E., Gowing, A., 2007. Bioconcentration of dioxins and furans in 668 vegetation. Water Air Soil Poll. 179, 117-124.

669 Sinha, S., Gopal, M., 2002. Evaluating the safety of $\beta$-cyfluthrin insecticide for usage in 670 eggplant (Solanum melongena L.) crop. B. Environ. Contam. Tox. 68, 400-405.

671 St-Amand, A.D., Mayer, P.M., Blais, J.M., 2007. Modeling atmospheric vegetation uptake of 672 PBDEs using field measurements. Environ. Sci. Technol. 41, 4234-4239.

673 Stahl, T., Heyn, J., Thiele, H., Hüther, J., Failing, K., Georgii, S., Brunn, H., 2009. Carryover 674 of perfluorooctanoic acid (PFOA) and perfluorooctane sulfonate (PFOS) from soil to plants. 675 Arch. Environ. Con. Tox. 57, 289-298. 
Stork, A., Ophoff, H., Smelt, J.H., Führ, F., 1998. Volatilization of pesticides: Measurements under simulated field conditions, in: Führ, F., Hance, R.J., Plimmer, J.R., Nelson, J.O. (Eds.), The Lysimeter Concept. American Chemical Society, Washington, D.C., pp. 21-39.

Takaki, K., Wade, A.J., Collins, C.D., 2014. Assessment of plant uptake models used in exposure assessment tools for soils contaminated with organic pollutants. Environ. Sci. Technol. 48, 12073-12082.

682 683

684

685

686

687

688

689

690

691

692

693

694

695

696

697

698

699

700

701

702

703

704

705

706

707

708

709

710

Trapp, S., 2015. Calibration of a plant uptake model with plant- and site-specific data for uptake of chlorinated organic compounds into radish. Environ. Sci. Technol. 49, 395-402.

Trapp, S., Cammarano, A., Capri, E., Reichenberg, F., Mayer, P., 2007. Diffusion of PAH in potato and carrot slices and application for a potato model. Environ. Sci. Technol. 41, 3103 3108.

Trapp, S., Legind, C.N., 2011. Uptake of organic contaminants from soil into vegetables and fruits, in: Swartjes, F.A. (Ed.), Dealing with Contaminated Sites - From Theory towards Practical Application. Springer Press, Dordrecht, pp. 369-408.

Trapp, S., Matthies, M., Scheunert, I., Topp, E.M., 1990. Modeling the bioconcentration of organic chemicals in plants. Environ. Sci. Technol. 24, 1246-1252.

Trapp, S., Mc Farlane, J.C., 1995. Plant Contamination. Lewis Publishers, Boca Raton, Florida.

U.S. EPA, 1996a. Occupational and residential exposure test guidelines: OPPTS 875.2000 Background for postapplication exposure monitoring test guidelines. United States Environmental Protection Agency, Washington, D.C.

U.S. EPA, 1996b. Occupational and residential exposure test guidelines: OPPTS 875.2100: Foliar dislodgeable residue dissipation. United States - Environmental Protection Agency, Washington, D.C.

U.S. EPA, 1996c. Occupational and residential exposure test guidelines: OPPTS 875.2900 Data reporting and calculations. United States - Environmental Protection Agency, Washington, D.C.

U.S. EPA, 1996d. Residue chemistry test guidelines: OPPTS 860.1300: Nature of the residue - plants, livestock. United States - Environmental Protection Agency, Washignton, D.C.

U.S. EPA, 1996e. Residue chemistry test guidelines: OPPTS 860.1340 Residue analytical method. United States - Environmental Protection Agency, Washington, D.C.

U.S. EPA, 1996f. Residue chemistry test guidelines: OPPTS 860.1360 Multiresidue method. United States - Environmental Protection Agency, Washington, D.C.

U.S. EPA, 1996g. Residue chemistry test guidelines: OPPTS 860.1380 Storage stability data. United States - Environmental Protection Agency, Washington, D.C.

U.S. EPA, 1996h. Residue chemistry test guidelines: OPPTS 860.1400 Water, fish, and irrigated crops. United States - Environmental Protection Agency, Washington, D.C. 
U.S. EPA, 1996i. Residue chemistry test guidelines: OPPTS 860.1500: Crop field trials. United States - Environmental Protection Agency, Washington, D.C.

U.S. EPA, 1996j. Residue chemistry test guidelines: OPPTS 860.1520 Processed food/feed. United States - Environmental Protection Agency, Washington, D.C.

U.S. EPA, 1996k. Residue chemistry test guidelines: OPPTS 860.1550 Proposed tolerances.

718 United States - Environmental Protection Agency, Washington, D.C.

U.S. EPA, 19961. Residue chemistry test guidelines: OPPTS 860.1850 Confined accumulation in rotational crops. United States - Environmental Protection Agency, Washington, D.C.

U.S. EPA, 1996m. Residue chemistry test guidelines: OPPTS 860.1900: Field accumulation in rotational crops. United States - Environmental Protection Agency, Washington, D.C.

U.S. EPA, 2008a. Fate, transport and transformation test guidelines - OPPTS 835.6100: Terrestrial field dissipation. United States - Environmental Protection Agency, Washington,

725 D.C.

U.S. EPA, 2008b. Fate, transport and transformation test guidelines - OPPTS 835.6300: Forestry dissipation. United States - Environmental Protection Agency, Washignton, D.C.

U.S. EPA, 2012a. Ecological effects test guidelines - OCSPP 850.4000: Background and special considerations - tests with terrestrial and aquatic plants, cyanobacteria, and terrestrial soil-core microcosms. United States - Environmental Protection Agency, Washington, D.C.

U.S. EPA, 2012b. Ecological effects test guidelines - OCSPP 850.4100: Seedling emergence and seedling growth. United States - Environmental Protection Agency, Washington, D.C.

U.S. EPA, 2012c. Ecological effects test guidelines - OCSPP 850.4150: Vegetative vigor. United States - Environmental Protection Agency, Washington, D.C.

U.S. EPA, 2012d. Ecological effects test guidelines - OCSPP 850.4230: Early seedling growth toxicity test. United States - Environmental Protection Agency, Washington, D.C.

U.S. EPA, 2012e. Ecological effects test guidelines - OCSPP 850.4300: Terrestrial plants field study. United States - Environmental Protection Agency, Washington, D.C.

U.S. EPA, 2012f. Ecological effects test guidelines - OCSPP 850.4800: Plant uptake and translocation test. United States - Environmental Protection Agency, Washington, D.C.

Undeman, E., Czub, G., McLachlan, M.S., 2009. Addressing temporal variability when modeling bioaccumulation in plants. Environ. Sci. Technol. 43, 3751-3756.

Undeman, E., McLachlan, M.S., 2011. Assessing model uncertainty of bioaccumulation models by combining chemical space visualization with a process-based diagnostic approach. Environ. Sci. Technol. 45, 8429-8436.

Walia, S., Boora, P., Kumari, B., 2010. Effect of processing on dislodging of cypermethrin residues on brinjal. B. Environ. Contam. Tox. 84, 465-468.

Weis, J.S., Weis, P., 2004. Metal uptake, transport and release by wetland plants: implications 
750 Willis, G.H., McDowell, L.L., 1987. Pesticide persistence on foliage. Rev. Environ. Contam. 751 T. 100, 23-73.

752

753 